\title{
Effect of Multi-enzymes Supplementation in Egg type Chicks Diet with Varying Protein and Energy levels During Hot-dry Summer
}

\author{
S. P. Dukare, A. B. Mandal, J. J. Rokade and O. P. Dinani*
}

ICAR-Central Avian Research Institute, Izatnagar, Uttar Pradesh (243 122), India

\author{
Corresponding Author \\ O. P. Dinani \\ e-mail:dr_dinani@rediffmail.com
}

\author{
Article History \\ Article ID: AR1837 \\ Received in $24^{\text {th }}$ August, 2017 \\ Received in revised form $29^{\text {th }}$ September, 2017 \\ Accepted in final form $6^{\text {th }}$ October, 2017
}

\begin{abstract}
An experiment was conducted to evaluate the effects of dietary inclusion of (multi-enzymes) maxi-zyme at different energy and protein level on performance of egg-type chicks during hot-dry summer. After feeding a standard diet from 0-21d of age, the chicks were randomly distributed into four dietary treatment groups viz., $\mathrm{T}_{1}$ with high energy $2800 \mathrm{kcal} \mathrm{ME} \mathrm{kg}^{-1}$ and high protein $18.0 \%$ (HEHP), T2 HEHP diet with maxi-zyme $0.025 \%$ and $\mathrm{T}_{3}$ with low energy $2700 \mathrm{kcal} \mathrm{ME} \mathrm{kg}^{-1}$ low protein $17.34 \%$ (LELP) and T4 with LELP diet with maxi-zyme $0.025 \%$. Each treatment is with fifty birds divided in five replicated of ten birds each. Experiment was carried out during hot-dry summer (April-May, $28.0 \pm 0.12{ }^{\circ} \mathrm{C}$ to $35.25 \pm 0.37^{\circ} \mathrm{C}$ and $\mathrm{RH} \%: 68.95 \pm 0.90$ to $79.15 \pm 0.61$ ). Production performance, immune organ weight, blood biochemical and intestinal morphometry were measured at $42^{\text {nd }}$ and $63^{\text {rd }}$ day post hatch. Body weight gain, Feed intake and FCR improved significantly $(\mathrm{P}<0.05)$ in $\mathrm{HEHP}+$ maxi-zyme group. $\mathrm{H}$ :L ratio significantly $(p<0.05)$ reduced in maxi-zyme supplemented group at $42^{\text {nd }}$ as well as $63^{\text {rd }}$ day of age. Immune organ like thymus, spleen and bursa had significantly $(p<0.05)$ higher weight in maxi-zyme supplemented group. Total protein $(p<0.001)$, SGOT $(p<0.001)$, SGPT $(p<0.001)$, creatinine $(p<0.05)$ were significantly improved while cholesterol, uric acid \& ALP was significantly $(p<0.001)$ reduced in maxi-zyme supplemented diets. Villus height \& crypt depth improved significantly $(p<0.001)$ in maxizyme supplemented group at $42^{\text {nd }}$ as well as $63^{\text {rd }}$ day of age. Thus, it was concluded that high-energy $\left(2800 \mathrm{kcal}^{\mathrm{ME}} \mathrm{kg}^{-1}\right)$ and high protein ( $18 \%$ CP) diet was beneficial for egg type starting chicks during dry summer. Moreover, the inclusion of maxi-zyme @ 0.025\% gave further advantage to improve performance and reduce thermal stress.
\end{abstract}

Keywords: Egg-type chicks, heat stress, maxi-zyme and nutritional plane

\section{Introduction}

There was continuous research is going on to improve nutritive value of feed by enzyme supplementation. In addition to the use of the conventional xylanase, glucanase, phytase, and, more recently, multi-carbohydrase preparations, the application of normal digestive tract enzymes (i.e., protease, amylase, lipase) have also been proposed (Jiang et al., 2008; Angel et al., 2011; Kalmendal and Tauson, 2012; Yegani and Korver, 2013). The application of these enzymes has been driven by the idea that newly hatched chicks may be deficient in key digestive enzymes; this has been corroborated by Nitsan et al. (1991); Noy and Sklan (1995); Jin et al. (1998), who showed that specific activities of lipase, amylase, and trypsin rapidly increase up to 2 to $3 \mathrm{wk}$ post hatch. Consequently, it has been suggested that the immaturity of the digestive system of young chicks may result in the poor utilization of dietary nutrients (Jin et al., 1998), and nutrient digestion rather than the ability to absorb nutrients has been indicated to be the primary limiting factor (Parsons, 2004). The use of exogenous enzymes in the diets of broilers is an important tool to reduce these costs. Even with highly digestible diets, such as those based on corn and soybean meal, the addition of enzymes may improve the dietary energy, and the gut viscosity may be decreased (Hahn-Didde and Purdum, 2014). However, according to (Choct, 2006), the benefits of including enzymes in broiler chicken nutrition include not only better performance but also environmental stress. Furthermore, the enzymes could improve the digestion and absorption of the majority of the nutrients prior to the establishment on environment which is favorable to bacterial growth (Bedford, 2000). Enzymes enhance nutrient delivery to the host and provide substrate (fermentable oligosaccharides) for the microbiota (Cowieson, 2012), consequently improving the intestinal health. Different blends of enzymes, with specificity to different substrates, may have beneficial effects in promoting the intestinal health of birds that are raised in poor environmental conditions. 


\section{Materials and Methods}

A feeding trial was conducted during 0 to 63 days of age in layer starting chicks to study the efficacy of maxi-zyme on performance during hot-dry summer (April-May, 28.0 \pm 0.12 ${ }^{\circ} \mathrm{C}$ to $35.25 \pm 0.37{ }^{\circ} \mathrm{C}$ and $\mathrm{RH}, \% 68.95 \pm 0.90$ to $79.15 \pm 0.61$ ) involving day-old CARI Sonali layer chicks $(n=200)$. After feeding standard diet for 0 to $21 \mathrm{~d}$ of age, the chicks were randomly distributed into four dietary treatment groups viz., $\mathrm{T}_{1}$ (high energy high protein-HEHP), $\mathrm{T}_{2}$ (HEHP diet with maxi-zyme @ 0.025\%). T (Low energy low protein-LELP) and T4 (LELP diet with maxi-zyme @ 0.025) each with fifty birds divided in five replicates of ten birds each up to 63 days of age. MOS was incorporated both in starter HEHP (18\% CP and $2800 \mathrm{kcal} \mathrm{ME} \mathrm{kg}^{-1}$ ) and LELP (17.34\% CP and $2700 \mathrm{kcal} \mathrm{ME} \mathrm{kg}^{-1}$ ) diets at two levels ( 0 or $0.025 \%$ ). The ingredient and chemical composition of diets are presented in Table 1.

Data regarding growth performance in the control and experimental group were recorded every week from 21-63 ${ }^{\text {rd }}$ days of age. Lymphoid organ weights (bursa of Fabricius, spleen, and thymus) were recorded on the $42^{\text {nd }}$ and $63^{\text {ed }}$ day expressed as percent (relative yield) of live weight. Blood samples $(1 \mathrm{ml})$ were collected from the wing vein using 24 gauge needles in $\mathrm{K}_{3}$-EDTA tubes on $42^{\text {nd }}$ and $63^{\text {rd }}$ day of age. Hemoglobin concentration ( $\mathrm{g} \mathrm{dl}^{-1}$ ) in the whole blood was estimated by cyano-methaemoglobin method. Blood smears prepared from fresh blood smear were stained by Giemsa stain (1:9 Dilution for $45 \mathrm{~min}$ ) to calculate Heterophil to lymphocyte $(\mathrm{H}: \mathrm{L})$ ratio. Serum samples were separated after blood collection and subjected to different blood biochemical tests like Aspartate aminotransferase (AST), Alanine aminotransferase (ALT), total protein and total cholesterol using standard KIT. On $42^{\text {nd }}$ and $63^{\text {rd }}$ day after slaughter jejunum samples were collected and histomorphology of villas height depth and the ratio was observed. The data were analyzed following $2 \times 2$ factorial designs (Snedechor and Cochran, 1989).

\section{Results and Discussion}

Weight gain differs significantly $(p<0.001)$ due to the incorporation of maxi-zyme in the diet in all the growth phases and the plane of nutrition during 43-63d of age. Reduced BWG has been reported in birds fed diets with low (Reece et al., 1984) and excessive (Cornejo et al., 1991) energy. It is thus beneficial for birds to consume diets with proper energy levels to optimize performance. Zanella et al. (1999) found that supplementation of Avizyme to corn soybean based diet had improved the body weight gain. Cowieson and coworkers (2006) reported a similar result in which higher BWG was observed in birds fed normal nutrients with enzyme supplementation. This might be a result of an incidental optimal dietary ratio of protein (or amino acid) to energy which stimulated enhanced FI and BWG (Bartov and Plavnik, 1998), while enzyme supplementation may have
Table 1: Ingredients and nutrient composition of basal diet used HEHP and LELP for hot and hot-humid summer

\begin{tabular}{|c|c|c|}
\hline Ingredients (kg $100 \mathrm{~kg}^{-1}$ ) & HEHP & LELP \\
\hline Yellow maize & 55.8 & 50.7 \\
\hline DORB & 12.935 & 21.475 \\
\hline Soybean meal & 18.7 & 15.3 \\
\hline Rapeseed meal & 5 & 5 \\
\hline Roasted guar & 5 & 5 \\
\hline Limestone powder & 1 & 1.1 \\
\hline Dicalcium phosphate & 0.95 & 0.75 \\
\hline Common salt & 0.3 & 0.3 \\
\hline Lysine & 0 & 0.06 \\
\hline TM premix 1 & 0.1 & 0.1 \\
\hline Vit premix 2 & 0.15 & 0.15 \\
\hline B comp & 0.015 & 0.015 \\
\hline Ch Chloride & 0.05 & 0.05 \\
\hline Total & 100 & 100.0 \\
\hline \multicolumn{3}{|c|}{ Nutrient composition (As fed basis) } \\
\hline $\mathrm{ME}, \mathrm{kcal} / \mathrm{kg}^{* * *}$ & 2800.41 & 2700.32 \\
\hline Crude Protein, $\%^{* *}$ & 17.99 & 17.33 \\
\hline Lysine, $\%{ }^{* * *}$ & 0.85 & 0.85 \\
\hline Methionine, $\%{ }^{* * *}$ & 0.33 & 0.33 \\
\hline Threonine & 0.83 & 0.77 \\
\hline Calcium, $\%^{* *}$ & 1.02 & 1.01 \\
\hline Total Phosphorus, $\%{ }^{* *}$ & 0.75 & 0.75 \\
\hline Available Phosphorus, $\%^{* * *}$ & 0.45 & 0.45 \\
\hline
\end{tabular}

Trace mineral premix includes 0.1 , vitamin premixes 0.15 . Trace mineral premix supplied Mg- 300, Mn- 55, I- 0.4, Fe- 56, Zn-30 and Cu- 4 mg kg-1 diet. The vitamin premixes supplied vitamin A 8250 IU, vitamin D 1200 ICU; vitamin $\mathrm{K} 1 \mathrm{mg}$; vitamin E $40 \mathrm{IU}$, vitamin $\mathrm{B}_{1} 2 \mathrm{mg}$, vitamin $\mathrm{B}_{2} 4 \mathrm{mg}$, vitamin $B_{12} 10 \mathrm{mcg}$; niacin $60 \mathrm{mg}$; pantothenic acid $10 \mathrm{mg}$ and choline chloride $500 \mathrm{mg} \mathrm{kg}^{-1}$ diet; Representative samples of practical feed ingredients and test diets used in the study were analyzed. (AOAC, 1990).

released additional energy and altered the ratio which limited $\mathrm{Fl}$ in birds.

Feed intake differs significantly $(p<0.001)$ due to the incorporation of maxi-zyme in the diet in all the growth phases and the plane of nutrition during 43-63d of age, while interaction was not significant at any growth phase. Kocher et al. (2002) reported that addition of multi-enzymes to cornsoybean based diet showed a decrease in the feed intake. The significantly improved feed conversion ratio in the presence of the multi-enzyme may be a consequence of decreasing microbial colonization in the gut, thereby improving the 
availability of nutrients.

The feed conversion ratio (FCR) differed significantly $(p<0.001)$ due to maxi-zyme as well as the plane of nutrition in all the phases ( 22 to 42,43 to 63 or 22 to $63 \mathrm{~d}$ of age) but the interaction of these two major effects did not influence FCR (Table 2). The birds with maxi-zyme fed diet had lower feed intake in all the growth phases. Zanella et al. (1999) observed that addition of Avizyme to corn-soybean based broiler diet improved the feed efficiency. Enzyme supplementation might improve broiler performance by improving nutrient digestibility. This mechanism might be induced, at least partially, by a reduction of the viscosity Lazaro et al. (2003). The relative higher protein retention may also have contributed to a better FCR due to reduced loss of endogenous secretion (Cowieson et al., 2003)

Though body weight gain did not differ due to the dietary plane but the values were apparently higher in HEHP diet. In contrary, body weight increased by increasing protein level from $18 \%$ to $20 \%$ CP (Toppo et al., 2004). In the present study increment of protein was much less and the ratio of energy to protein remained similar, which might be the possible reasons for a similar gain in body weight. Feed intake increased in low energy low protein diet, which may be attributed to dietary energy concentration. The feed intake increased significantly with low energy diet ( 2600 vs. $2800 \mathrm{kcal} \mathrm{ME} \mathrm{kg}^{-1}$ ) but there was no change in total feed intake by increasing crude protein levels from 18 to $22 \%$ at any energy level (Toppo et al., 2004). Feed conversion ratio was significantly $(p<0.05)$ poor in low

\begin{tabular}{|c|c|c|c|c|c|c|c|c|c|c|}
\hline EP & $\begin{array}{l}\text { Maxi- } \\
\text { zyme }\end{array}$ & $\begin{array}{c}\text { BWG } \\
\text { (3-6 wk) }\end{array}$ & $\begin{array}{c}\text { BWG } \\
(6-9 w k)\end{array}$ & $\begin{array}{c}\text { BWG } \\
\text { (3-9 wk) }\end{array}$ & $\begin{array}{c}\mathrm{FI} \\
\text { (3-6 wk) }\end{array}$ & $\begin{array}{c}\mathrm{Fl} \\
(6-9 w k)\end{array}$ & $\begin{array}{c}\mathrm{FI} \\
\text { (3-9 wk) }\end{array}$ & $\begin{array}{c}\text { FCR } \\
(3-6 \mathrm{wk})\end{array}$ & $\begin{array}{c}\text { FCR } \\
(6-9 \mathrm{wk})\end{array}$ & $\begin{array}{c}\text { FCR } \\
\text { (3-9 wk) }\end{array}$ \\
\hline HEHP & 0 & 230.2 & 360.3 & 589.5 & 772 & 1283 & 2040 & 3.35 & 3.26 & 3.46 \\
\hline HEHP & 0.025 & 246.3 & 402.5 & 650.3 & 736 & 1119 & 1816 & 2.98 & 2.78 & 2.79 \\
\hline LELP & 0 & 220.8 & 365.9 & 598.0 & 815 & 1405 & 2206 & 3.69 & 3.83 & 3.68 \\
\hline LELP & 0.025 & 245.6 & 418.7 & 619.9 & 742 & 1213 & 1845 & 3.02 & 2.89 & 2.97 \\
\hline SEM & 2.85 & 7.82 & 9.83 & 7.18 & 31.37 & 33.29 & 0.05 & 0.05 & 0.02 & \\
\hline HEHP & & $230.2 b$ & $381.4 b$ & $619.9 b$ & $754 b$ & $1201 b$ & $1928 b$ & $3.17 b$ & $3.17 b$ & $3.12 b$ \\
\hline LELP & & $233.2 \mathrm{a}$ & 392.3a & $608.9 a$ & $778 a$ & $1309 a$ & $2025 a$ & $3.35 a$ & $3.36 a$ & $3.33 a$ \\
\hline Maxi-zyme & 0 & $225.5 x$ & $363.2^{x}$ & $593.7^{x}$ & $793^{x}$ & $1344^{x}$ & $2123^{x}$ & $3.52^{x}$ & $3.70^{x}$ & $3.57^{x}$ \\
\hline Maxi-zyme & 0.025 & $245.9^{y}$ & $410.6^{y}$ & $635.1^{y}$ & $739^{y}$ & $1166^{y}$ & $1830^{y}$ & $3.00^{y}$ & $2.83^{y}$ & $2.88^{y}$ \\
\hline \multicolumn{11}{|l|}{ Probability } \\
\hline EP & & $p<0.03$ & $p<0.03$ & $p<0.03$ & $p<0.03$ & $p<0.03$ & $p<0.03$ & $p<0.03$ & $p<0.03$ & $p<0.03$ \\
\hline Maxi-zyme & & $p<0.001$ & $p<0.001$ & $p<0.001$ & $p<0.001$ & $p<0.001$ & $p<0.001$ & $p<0.01$ & $p<0.001$ & $p<0.001$ \\
\hline EP X Maxi-zyme & & NS & NS & NS & NS & NS & NS & NS & NS & NS \\
\hline
\end{tabular}

abxyValues bearing different superscript differed significantly $(p<0.01)$; NS, Non significant

energy low protein diet as in earlier experiment FCR remained poor than in high energy level in CARI Sonali chicks, and feed conversion ratio tended to be higher at low protein (18\%) diet (Toppo et al., 2004).

Supplementation of maxi-zyme caused significant improvement in relative weights of spleen, thymus, and bursa during 43 to $63 \mathrm{~d}$ post-hatch during hot humid climate (Table $3)$. There was no interaction and different energy protein level effect. In the present study, significantly $(p<0.001)$ lower $\mathrm{H}: \mathrm{L}$ ratio in maxi-zyme fed bird as compared to control birds in HEHP and LELP feed during $42^{\text {nd }}$ and $63^{\text {rd }} \mathrm{d}$ of age (Table 4 and Table 5).

The serum total protein was significantly $(p<0.001)$ higher in maxi-zyme supplemented birds as compared to control in both HEHP and LELP birds at 43 to $63 \mathrm{~d}$ of age during hot dry summer (Table 4 and 5). Maxi-zyme supplementation significantly $(p<0.001)$ reduced the serum cholesterol concentration during 43 to $63 \mathrm{~d}$ of age as compared to unsupplemented birds in both HEHP and LELP during hot-dry summer. During 43 to $63 \mathrm{~d}$ of age aspartame aminotransferase (AST) and alanine aminotransferase (ALT) levels increased significantly $(p<0.001)$ with higher concentration in maxi-zyme fed birds as compared to control birds in both HEHP and LELP feed. Maxi-zyme supplementation significantly $(p<0.001)$ reduced the serum Alkaline Phosphates concentration during 43 to $63 \mathrm{~d}$ of age as compared to control birds in both HEHP and LELP during hot summer. Maxi-zyme supplementation significantly $(p<0.001)$ reduced the serum uric acid concentration at $42^{\text {nd }}$ and $63^{\text {rd }}$ day of age as compared to control birds in both HEHP and LELP during hot-dry summer. During 43 to $63 \mathrm{~d}$ of age, creatinine levels increased significantly $(p<0.001)$ with supplementation of maxi-zyme fed birds as compared to control birds in both HEHP and LELP. During $42^{\text {nd }}$ and $63^{\text {rd }} d$ of age, villus height 


\begin{tabular}{|c|c|c|c|c|c|c|c|c|c|}
\hline \multirow[t]{2}{*}{ EP } & \multirow{2}{*}{\multicolumn{2}{|c|}{$\begin{array}{c}\text { Maxi-zyme } \\
(\%)\end{array}$}} & \multicolumn{3}{|c|}{6 week } & \multicolumn{4}{|c|}{9 week } \\
\hline & & & Thymus & Bursa & Spleen & \multicolumn{2}{|c|}{ Thymus } & Bursa & Spleen \\
\hline \multirow[t]{2}{*}{ HEHP } & \multicolumn{2}{|c|}{0} & 0.292 & 0.120 & 0.216 & 0.52 & & 0.112 & 0.202 \\
\hline & \multicolumn{2}{|c|}{0.025} & 0.367 & 0.181 & 0.294 & 0.48 & & 0.195 & 0.298 \\
\hline \multirow[t]{2}{*}{ LELP } & \multicolumn{2}{|c|}{0} & 0.291 & 0.128 & 0.211 & 0.50 & & 0.119 & 0.216 \\
\hline & \multicolumn{2}{|c|}{0.025} & 0.373 & 0.143 & 0.274 & 0.44 & & 0.189 & 0.289 \\
\hline SEm \pm & \multicolumn{2}{|c|}{0.01} & 0.01 & 0.01 & 0.02 & \multicolumn{2}{|c|}{0.01} & 0.01 & \\
\hline HEHP & & & 0.329 & 0.150 & 0.255 & 0.50 & & 0.153 & 0.250 \\
\hline LELP & & & 0.332 & 0.135 & 0.242 & 0.47 & & 0.154 & 0.252 \\
\hline Maxi-zyme & \multicolumn{2}{|c|}{0} & $0.291^{x}$ & $0.124^{x}$ & $0.213^{x}$ & 0.51 & & $0.115^{x}$ & $0.209^{x}$ \\
\hline Maxi-zyme & \multicolumn{2}{|c|}{0.025} & $0.370 y$ & $0.162^{y}$ & $0.284^{y}$ & 0.46 & & $0.192^{y}$ & $0.293^{y}$ \\
\hline \multicolumn{10}{|l|}{ Probability } \\
\hline \multicolumn{3}{|l|}{ EP } & NS & NS & NS & \multicolumn{2}{|c|}{ NS } & NS & NS \\
\hline \multicolumn{3}{|l|}{ Maxi-zyme } & $p>0.001$ & $p>0.001$ & $p>0.001$ & \multicolumn{2}{|c|}{$p>0.003$} & $p>0.003$ & $p>0.000$ \\
\hline \multicolumn{3}{|l|}{ EP X Maxi-zyme } & NS & NS & NS & \multicolumn{2}{|c|}{ NS } & NS & NS \\
\hline \multicolumn{10}{|c|}{ abxyValues bearing different superscript differed significantly ( $p<0.01)$; NS: Non significant } \\
\hline \multicolumn{10}{|c|}{ Table 4: Blood biochemical parameter and H:L ratio at 6 weeks of age in different treatments } \\
\hline EP & $\begin{array}{l}\text { Maxi- } \\
\text { zyme }\end{array}$ & Protein & SGOT & SGPT & $\begin{array}{c}\text { Choles- } \\
\text { terol }\end{array}$ & Uric acid & $\begin{array}{c}\text { Alkaline } \\
\text { P }\end{array}$ & $\begin{array}{l}\text { Cre- } \\
\text { atine }\end{array}$ & $\mathrm{H}: \mathrm{L}$ ratio \\
\hline \multirow[t]{2}{*}{ HEHP } & 0 & 3.14 & 84.44 & 2.81 & 171.56 & 5.47 & 46.70 & 0.69 & 0.47 \\
\hline & 0.025 & 4.28 & 108.25 & 3.72 & 136.32 & 3.78 & 33.53 & 0.78 & 0.38 \\
\hline LELP & 0 & 3.08 & 91.37 & 2.90 & 182.65 & 5.61 & 48.27 & 0.71 & 0.45 \\
\hline & 0.025 & 4.13 & 106.26 & 3.69 & 153.71 & 3.91 & 35.82 & 0.80 & 0.37 \\
\hline Sem & 0.04 & 0.61 & 0.07 & 0.81 & 0.07 & 0.74 & 0.01 & 0.01 & \\
\hline HEHP & & $3.71 a$ & 96.34 & 3.26 & 153.94 & 4.62 & 40.11 & 0.73 & 0.42 \\
\hline LELP & & $3.60 b$ & 98.81 & 3.29 & 168.18 & 4.76 & 42.04 & 0.75 & 0.41 \\
\hline Maxi-zyme & 0 & $3.11^{x}$ & $87.90^{x}$ & $2.85^{x}$ & $177.10^{x}$ & $5.54^{x}$ & $47.48^{x}$ & $0.70^{x}$ & $0.46^{x}$ \\
\hline Maxi-zyme & 0.025 & $4.20 y$ & $107.25 y$ & $3.70 y$ & $145.01^{y}$ & $3.84^{y}$ & $34.67^{y}$ & $0.79^{y}$ & $0.37^{y}$ \\
\hline Probability & & & & & & & & & \\
\hline EP & & NS & NS & NS & NS & NS & NS & NS & NS \\
\hline Maxi-zyme & & $p>0.000$ & $p>0.000$ & $p>0.000$ & $p>0.000$ & $p>0.000$ & $p>0.00$ & $p>0.00$ & $p>0.003$ \\
\hline EP X Maxi-zyme & & NS & NS & NS & NS & NS & NS & NS & NS \\
\hline
\end{tabular}

abxyValues bearing different superscript differed significantly $(p<0.01)$; NS: Non significant

Table 5: Blood biochemical parameter and H:L ratio at 9 weeks of age in different treatments

\begin{tabular}{|c|c|c|c|c|c|c|c|c|c|}
\hline EP & Maxi-zyme & Protein & SGOT & SGPT & Cholesterol & Uric acid & Alkaline P & Creatine & H:L ratio \\
\hline \multirow[t]{2}{*}{ HEHP } & 0 & 3.80 & 72.67 & 2.82 & 181.73 & 5.71 & 54.87 & 0.78 & 0.41 \\
\hline & 0.025 & 5.47 & 108.22 & 3.47 & 135.47 & 3.62 & 36.72 & 0.72 & 0.34 \\
\hline \multirow[t]{2}{*}{ LELP } & 0 & 3.74 & 71.71 & 2.89 & 183.29 & 5.74 & 56.81 & 0.76 & 0.42 \\
\hline & 0.025 & 5.63 & 105.87 & 3.27 & 138.78 & 3.37 & 38.55 & 0.70 & 0.33 \\
\hline SEm \pm & & 0.08 & 0.98 & 0.09 & 1.51 & 0.08 & 0.79 & 0.01 & 0.01 \\
\hline
\end{tabular}




\begin{tabular}{lccccccccc}
\hline & & & & & & & \\
\hline EP & Maxi-zyme & Protein & SGOT & SGPT & Cholesterol & Uric acid & Alkaline P & Creatine & H:L ratio \\
\hline HEHP & & 4.63 & 90.44 & 3.14 & 158.60 & 4.66 & 45.79 & 0.75 & 0.37 \\
LELP & & 4.68 & 88.79 & 3.08 & 161.03 & 4.55 & 47.68 & 0.73 & 0.37 \\
Maxi-zyme & 0 & $3.77^{x}$ & $72.19^{x}$ & $2.85^{x}$ & $182.51^{x}$ & $5.72^{x}$ & $55.84^{x}$ & $0.77^{x}$ & $0.41^{x}$ \\
Maxi-zyme & 0.025 & $5.55 y$ & $107.04^{y}$ & $3.37^{y}$ & $137.12^{y}$ & $3.49^{y}$ & $37.63^{y}$ & $0.71^{y}$ & $0.33^{y}$ \\
Probability & & & & & & & & & \\
EP & & NS & NS & NS & NS & NS & NS & NS & NS \\
Maxi-zyme & $p>0.00$ & $p>0.00$ & $p>0.00$ & $p>0.00$ & $p>0.00$ & $p>0.00$ & $p>0.04$ & $p>0.01$ \\
EP×Maxi-zyme & & NS & NS & NS & NS & NS & NS & NS & NS \\
\hline
\end{tabular}

abxy Values bearing different superscript differed significantly $(p<0.01)$; NS, Non significant

increased significantly $(p<0.001)$ with a higher value in maxizyme fed birds as compared to control birds in both HEHP and LELP feed. Maxi-zyme supplementation significantly $(p<0.001)$ reduced the crypt depth during $42^{\text {nd }}$ and $63^{\text {rd }} \mathrm{d}$ of age as compared to control birds in both HEHP and LELP feed during hot-dry summer.

\section{Conclusion}

High-energy (2800 kcal ME kg$\left.{ }^{-1}\right)$ and high protein (18\% CP) diet was beneficial for egg type starting chicks during dry summer. Moreover, the inclusion of maxi-zyme @ 0.2\% gave further advantage to improve performance and reduce thermal stress as evidenced through zoo-technical indices and blood biochemicals.

\section{References}

Angel, C.R., Saylor, W., Vieria, S.L., Ward, N., 2011. Effects of a monocomponent protease on performance and protein utilization in 7- to 22-day-old broiler chickens. Poultry Science 90, 2281-2286.

AOAC, 1990. Association of Official Analytical Chemists. Official Methods of Analysis. 14 ${ }^{\text {th }}$ (Edn.), Washington, DC.

Bartov, I., Plavnik, I., 1998. Moderate excess of dietary protein increases breast meat yield of broiler chicks. Poultry Science 77, 680-688.

Bedford, M.R., 2000. Exogenous enzymes in monogastric nutrition-their current value and future benefits. Animal Feed Science and technology 86, 1-13.

Choct, M., 2006. Enzymes for the feed industry: past, present and future. World's Poultry Science Journal 62, 5-16.

Cowieson, A.J., Singh, D.N., Adeola, O., 2006. Prediction of ingredient quality and the effect of a combination of xylanase, amylase, protease and phytase in the diets of broiler chicks. 1. Growth performance and digestible nutrient intake. British Poultry Science 47, 477-489.

Cowieson, A.J., Acamovic, T., Bedford, M.R., 2003. Supplementation of diets containing pea meal with exogenous enzymes: effects on weight gain, feed conversion, nutrient digestibility and gross morphology of the gastrointestinal tract of growing broiler chicks. British Poultry Science 44, 427-437.

Hahn-Didde, D., Purdum, S.E., 2014. The effects of an enzyme complex in moderate and low nutrient-dense diets with dried distiller's grains with soluble in laying hen. The Journal of Applied Poultry Research 23, 23-33.

Jiang, Z., Zhou, Y., Lu, F., Han, Z., Wang, T., 2008. Effects of different levels of supplementary alpha-amylase on digestive enzyme activities and pancreatic amylase mRNA expression of young broilers. Asian-Australasian Journal of Animal Science 21, 97-102.

Jin, S.H., Corless, A., Sell, J.L., 1998. Digestive system development in post-hatch poultry. World's Poultry Science Journal 54, 335-345.

Kalmendal, R., Tauson, R., 2012. Effects of a xylanase and protease, individually or in combination, and an ionophore coccidiostat on performance, nutrient utilization, and intestinal morphology in broiler chickens fed a wheat-soybean meal-based diet. Poultry Science 91, 1387-1393.

Kocher, A., Choct, M., Porter, M.D., Broz, J.J., 2002. Effects of feed enzymes on nutritive value of soybean meal fed to broilers. British Poultry Science 43, 54-63.

Lazaro, R., Garcia, M., Medel, P., Mateos, G.G., 2003. Influence of enzymes on performance and digestive parameters of broilers fed rye-based diets. Poultry Science 82, 132-140.

Nitsan, Z., Duntington, E.A., Siegel, P.B., 1991. Organ growth and digestive enzyme levels to fifteen days of age in lines of chickens differing in body weight. Poultry Science 70, 2040-2048.

Noy, Y., Sklan, D., 1995. Digestion and absorption in the young chick. Poultry Science 74, 366-373.

Parsons, C.M., 2004. Gastrointestinal development and nutrient digestion in chicks. Pages 169-176 in Proceedings of the $25^{\text {th }}$ Western Nutrition Conference, Saskatoon, Canada. University of Saskatchewan, Saskatoon, Canada. 
Reece, F.N., Lott, B.D., Deaton, J.W., 1984. The effects of feed form, protein profile, energy level, and gender on broiler performance in warm $\left(26.7^{\circ} \mathrm{C}\right)$ environments. Poultry Science 63, 1906-1911.

Snedecor, G.W., Cochran, W.G., 1989. Statistical Methods. $7^{\text {th }}$ edn. Oxford and IBH.

Yegani, M., Korver, D.R., 2013. Effects of corn source and exogenous enzymes on growth performance and nutrient digestibility in broiler chickens. Poultry Science $92,1208-1220$.

Zanella, I., Sakomura, N.K., Silversides, F.G., Fiquelrdo, A.,
Pack, M., 1999. Effect of enzyme supplementation of broiler diets based on corn and soybeans. Poultry Science 78, 561-568.

Cornejo, S., Lopez, A., Pokniak, J., 1991. Effect of energy/ protein ratio on performance and carcass composition of male broilers. Journal of Veterinary Medicine 38, 126-133.

Toppo, S., Mandal, A.B., Elangovan, A.V., 2004. Dietary energy and protein requirements of egg type (CARI Sonali) starting chicks. Animal Nutrition \& Feed Technology 4, 17-22. 